\title{
THE WINTER-HARDINESS OF THE VARIETIES AND FORMS OF FILBERT (CORYLUS DOMESTICA KOSENKO ET OPALKO), PLANTED IN UKRAINE
}

\author{
Oleksandr Balabak \\ Department of Genetics, Selection and Reproductive Biology of Plants \\ National Dendrological Park "Sofievka" NAS of Ukraine \\ 12 a Kyivska str., Uman, Ukraine, 20300 \\ o.a.balabak@ukr.net
}

\begin{abstract}
The results of the study of winter-hardiness of the varieties and forms of filbert (Corylus domestica Kosenko et Opalko), planted in Ukraine, are presented. The aim was to determine the suitableness of filbert plants for industrial planting in the gardening zone of Ukraine that needed the most exact assessment of potential of their winter and frost resistance. For attaining this aim we introduced in the research the laboratory freezing of tissues and organs of prospective varieties of filbert with modeling of influence of the low negative temperatures at the level $-25,-30$ and $-35^{\circ} \mathrm{C}$. As the material of research were used the filbert plants of varieties and forms, prospective for planting in Ukrainian conditions. The study and procurement of slip material was carried out in parent filbert plants of decennial age of research-productive district of the National dendrologic part "Sofiivka", NAS of Ukraine during 2015-2016 according to conventional methods and recommendations. Incomplete coincidence of the data of frost resistance of studied filbert variants in the natural conditions and at the different modes of direct freezing can be explained by the varietal features. Despite the unfavorable conditions of wintering 2015-2016, the freezing of studied filbert plants under the garden conditions was completely insufficient (summary point of damage was less 10) and insufficient (the level of disorder is limited by $11-20$ points). Besides the ability to endure the short-term strong frosts, the high winter-hardiness is demonstrated only by filbert plants, less sensitive to the provoking influence of thaw.

The complex assessment of the winter and frost resistance of filbert plants by the field and instrumental methods proved the sufficient adaptability of studied samples to the conditions of studied gardening zone. The varieties and forms of filbert Sofiiivsky-1 and especially Pavlenko's gift were recognized as the best by the frost resistance and potential of winter-hardiness.

Keywords: filbert varieties, winter-hardiness, temperature, freezing, nuciferous plants, leaves, spouts, buds, introduction, productivity.
\end{abstract}

\section{Introduction}

Among the prospective arboraceous plants of natural and cultural flora the special place is occupied by nuciferous plants, especially the representative of Corylus L. genus - varietal filbert (Corylus domestica Kosenko et Opalko), that has not only nutritive value but positive influence on human health, is used in the garden-park economy, different industrial branches, in widening of selective-genetic fund at creation of new varieties, forms and hybrids [1,2]. It is a valuable culture that gives the important nutritive product. Its nuts are rich in nutritive substances and it exceeds the meat and fish by caloric content (more than $700 \mathrm{kcal}$ ) [3-5].

The filbert has a subtropical origin from the regions of Turkey and Caucasus, adjacent to the Black sea $[6,7]$. This culture differs by sufficient plasticity that made possible its planting in more Northern gardening zones. At the same time the active advancement of filbert fruits production farther to the North needs more winter and frost resistance of this crop. Under Ukrainian conditions the cold period of the year is differ by the variegated temperature mode. The strong frosts can be fast replaced by the numerous thaws $[8,9]$. The filbert as subtropical and wind-pollinated crop is characterized with the short period of organic rest, especially relative to the male racemes. The conditions of wintering provoke the early going out from the rest state and essential loss of winter-hardiness of the filbert plants [10-12].

In the state of deep rest the filbert plants are able to endure the effect of low negative temperatures up to $-30-35^{\circ} \mathrm{C}$. In the state of forced rest the plants of this culture essentially freeze already at $-15-20^{\circ} \mathrm{C}[13,14]$. It must be noted that in last decades in Ukraine the stable transfer of average daily temperature over $0^{\circ} \mathrm{C}$ in autumn that marks the beginning of winter essentially 
shifted and is often registered only in December. The long-term thaws with daily temperature higher $5-10{ }^{\circ} \mathrm{C}$ became more often. All aforesaid phenomena extremely powerfully provoke the loss of winter and frost resistance by the filbert plants. The selection of varieties of this crop, able to keep the acquired level of winter-hardiness under unstable weather conditions better, will favor the industrial production of filbert fruits in more Northern gardening zones of Ukraine [15-17].

The suitableness of filbert plants to the industrial planting in certain gardening zone of Ukraine that needed the most exact assessment of potential of their winter and frost resistance. For attaining this aim we introduced in the research the laboratory freezing of tissues and organs of prospective varieties of filbert with modeling of influence of the low negative temperatures at the level $-25,-30$ and $-35^{\circ} \mathrm{C}[18-20]$.

\section{Aim of research}

The aim of our research was the complex assessment of frost resistance of representatives of Corylus L. genus, planted in Ukraine, especially the varieties and forms of filbert (Corylus domestica Kosenko et Opalko).

\section{Materials and methods}

The winter-hardiness of filbert is not genetically conditioned constant. This property essentially depends on the conditions of vegetative period that precedes the wintering of plants of this culture. More precise determination of winter and frost resistance of the filbert varieties needed detailed analysis of the weather conditions where the plants were placed during whole period of the study.

As the material of research were used the filbert plants of varieties and forms, prospective for planting in Ukrainian conditions. The study and procurement of slip material was carried out in parent filbert plants of decennial age of research-productive district of the National dendrologic part "Sofiivka", NAS of Ukraine during 2015-2016 according to conventional methods and recommendations. The complexity of these studies, the diversity of applied methods (including instrumental ones) and significant volume of experimental data allowed us to consider the plants of this variety as physiological control of frost resistance at the assessment of prospective filbert varieties in the new gardening zone [21-23].

\section{Results of research}

The summer of 2015 was hot (the average temperature exceeded norm by $2-3{ }^{\circ} \mathrm{C}$ ), and its second half was droughty (precipitation in July-August were less than norm almost by $82 \mathrm{~mm}$ ). The same situation was at the beginning of autumn. During September of 2015 the heightened air temperature was registered, the precipitation quantity was also less than average norm of many years. The stable transfer of the average daily air temperature over $0{ }^{\circ} \mathrm{C}$ was detected only at the end of December. December of 2015 was characterized with both absence of the snow coat and little quantity of precipitations (six times less than the average norm of many years).

It is known that the period of active lignification of sprouts and also hidden growth and differentiation of filbert flowers is at the end of summer and beginning of autumn. The aforesaid weather conditions of vegetative period of 2015 provoked the prolonged growth of filbert plants, so did not favor the normal ripening of sprouts and preparation of plants to the wintering. At the same time the daily air temperatures more than $5{ }^{\circ} \mathrm{C}$ in December of 2015 induced the loss of acquired winter-hardiness level by the filbert plants, first of all by generative organs and transfer from the state of deep (organic) rest to the forced one.

At the beginning of January of 2016 was registered the abrupt and strong decrease of the air temperature that II decade of this month changed to the no less powerful thaw with increase of daily air temperature to $8^{\circ} \mathrm{C}$. Such weather conditions provoked the further loss of the level of winter-hardiness, acquired in vegetative period of 2015 by the filbert plants. The new powerful decrease of temperature at the beginning of III decade of January of 2016 was the extreme danger for generative formations of the filbert. After that at the end of January the thaw was registered again. During February of 2016 the weather was extremely warm. The positive daily temperature data 
provoked the going out of the state of forced rest by filbert plants. Accordingly, the studied varieties continued to loose the acquired level of winter and frost resistance.

The warm weather of I decade of March of 2016 initiated the blossoming of filbert plants. During II-III the weather was cool but the light frosts were not registered. Such weather conditions had to restrain the growth of pollen tubes but not to impede the process of pollination and fertilization of the studied filbert plants. At the beginning of April of 2016 the warm weather abruptly changed to the fall of temperature. The light frosts on soil were registered. The aforesaid weather phenomena of 2016 created the wonderful conditions for the assessment of filbert plants by resistance to the late spring light frosts (IV component of winter-hardiness). May was cool and pluvial, the light frosts on soil were not registered.

In whole the weather conditions of summer-autumn period of $2015 \mathrm{did}$ not favor the normal preparation of filbert plants to the wintering. The winter of 2015-2016 was characterized with extremely variegated, sometimes abnormal temperature mode that permanently induced the loss of acquired level of winter and frost resistance by the studied plants. This winter period was demonstrative for the assessment of winter and frost resistance of the filbert. It differed by such number of factors, unfavorable for the normal wintering of the filbert, which study usually needs the essentially more period of time: prolonged growth of sprouts and delay of the end of vegetative period of 2015 snowless winter of 2015-2016, insufficient store of moisture in the soil (that increased the danger of root freezing), permanent change of essential frost periods to the provoking thaws on the background of very significant amplitude and frequency of temperature fluctuations, provocation of the premature beginning of vegetation and blossoming of studied plants, late spring light frosts of 2016. All aforesaid stress-factors of 2015-2016 gave the extremely valuable experimental material for the assessment of the different varieties and forms of filbert not only by the frost resistance but by the resistance to the most of unfavorable wintering conditions.

Despite the aforesaid unfavorable conditions of the wintering of 2015-2016, the freezing of the studied filbert plants under conditions of the garden was very insignificant (summary point of damage was less 10) and insufficient (the level of disorder is limited by 11-20 points).

It must be noted, that according to the studies, the plants of Lozivsky ball-shaped variety are characterized with the high frost resistance in Ukrainian conditions.

The frosty damages of the plants of Lozivsky ball-shaped variety were insignificant in winter of 2015-2016. The point of cambium damage (the most important tissue for life activity of the plant, on whole length of one-year sprout was 0,9-1,5 (of 5 possible). The frost resistance of other tissues of one-year sprout of Lozivsky ball-shaped filbert was also inferior to the most variants of experiment. But the degree of frost damage of bark, wood, pith of one-year sprouts of this variant was low and did not exceed 2 points. The buds of aforesaid variants under conditions of the garden froze by 2,8 points (the middle level of freezing). The aforesaid frost damages of tissues and organs of Lozivsky ball-shape filbert did not create danger for the normal growth and development of plants in whole. At the same time the plants of other studied varieties manifested the better frost resistance in garden conditions. To the group of frost resistant according to the summary point of frost damage can be related the filbert plants of the following varieties (in the direction of increase of the sign manifestation): Lozivsky ball-shape $<$ Koronchaty $<$ Trapezund $<$ Dolinsky $<$ $<$ Sofiivsky-15 $<$ Galle $<$ Ukraine $50<$ Dokhidny=ordinary filbert $<$ Zujdivsky $<$ Filbert $85=$ Masterpiece (Table 1).

To the group of very frost resistant plants under the garden conditions can be related the variants: Sofiivsky- $1<$ Badius $<$ Futkurami $<$ Cherkesky- $2<$ Pavlenko's gift. The summary point of freezing of one-year sprout and buds of these varieties was 3,7-10,0. Let's note the high resistance to freezing of the buds of following filbert varieties: Ukraine-50, Galle, Sofiivsky-15, Zujdivsky (frost damage was weak, by 1,9 points); Koronchaty, Dolinsky (1,8 points); Sofiivsky 1 (1,7 points); Pavlenko's gift (1,2 points). The plants of the last specie differed by the very high stableness to the frost damages. Thus, the cambium freezing in this variant was only $0-0,4$ on whole length of one-year sprout. The damage of bark, wood and pith was mainly $0,2-0,3$ points (very insignificant). The buds and anthers froze the least among all variants of experiment (by 0,3 and 1,2 points respectively). 
Table 1

The frost damages of one-year sprouts, anthers and buds of the varieties and forms of filbert under the garden conditions, point, winter of 2015-2016

\begin{tabular}{|c|c|c|c|c|c|c|}
\hline \multirow{2}{*}{ Variety, specie } & \multirow{2}{*}{ Anthers } & \multicolumn{5}{|c|}{ Summary point of damage of tissues and buds of one-year sprout } \\
\hline & & Top of sprout & Middle of sprout & Tissues of bud & Node with bud & Totally \\
\hline Pavlenko’s gift & 0,3 & 0,9 & 1 & 1,2 & 1,8 & 3,7 \\
\hline Sofiivsky-1 & - & 3,1 & 3,1 & 1,7 & 3,8 & 10,0 \\
\hline Dolinsky & 2,0 & 4,5 & 4 & 1,8 & 5,1 & 13,6 \\
\hline Zujdivsky & 1,6 & 4,3 & 3,1 & 1,9 & 3,6 & 11,0 \\
\hline $\begin{array}{l}\text { Ordinary filbert } \\
\text { (control) }\end{array}$ & - & 3,9 & 3,2 & 2,0 & 4 & 11,1 \\
\hline Sofiivsky-15 & - & 4,5 & 3,1 & 1,9 & 5,1 & 12,7 \\
\hline Coronchaty & - & 5,3 & 3,9 & 1,8 & 5,1 & 14,3 \\
\hline Galle & - & 3,9 & 3,9 & 1,9 & 4,6 & 12,4 \\
\hline Masterpiece & 1,3 & 3,5 & 2,8 & 2,3 & 4,1 & 10,4 \\
\hline Filbert 85 & 1,6 & 3,5 & 3 & 2,7 & 4 & 10,5 \\
\hline Lozivsky ball-shaped & - & 6 & 4,7 & 2,8 & 6,4 & 17,1 \\
\hline Cherkesky & - & 3,1 & 2,6 & 3,0 & 3,7 & 9,4 \\
\hline Fukturami & - & 3,1 & 2,5 & 2,3 & 4,1 & 9,7 \\
\hline Dokhidny & 1,5 & 4,1 & 2,6 & 2,9 & 4,4 & 11,1 \\
\hline Trapezund & 3,0 & 3,4 & 4,5 & 2,8 & 6,2 & 14,1 \\
\hline Badius & - & 2,9 & 2,6 & 2,2 & 3,3 & 8,8 \\
\hline Ukraine-50 & - & 4,1 & 3,1 & 1,9 & 4,7 & 11,9 \\
\hline
\end{tabular}

The freezing of tissues and organs of the studied filbert varieties after artificial freezing with temperature factor $-35^{\circ} \mathrm{C}$ was mainly middle and weak. The most damages were received by the varieties Trapezund and Futkurami. The summary point of plants freezing in these variants was 31and 30,5 respectively. Most variants of experiment at freezing temperature $-35{ }^{\circ} \mathrm{C}$ were characterized with the middle level of damage. The high frost resistance was inherent to the filbert plants of the variety Pavlenko's gift and ordinary filbert. Close to these variants was the resistance of Sofiivsky-1 variety. Obviously, these three aforesaid variants had the least reaction to the provoking thaws of the winter of 2015-2016 so, kept the acquired potential of winter and frost resistance better (Table 2).

The frost resistance of the studied filbert plants at artificial freezing with temperature factor $-35^{\circ} \mathrm{C}$ in the cut of varieties increased as following:Trapezund $<$ Futkurami $<$ Masterpiecep $<$ $<$ Koronchaty $<$ Lozivsky ball-shaped $<$ Ukraine $50<$ Dokhidny $<$ Cherkesky $<$ Filbert $85<$ Badius $<$ Dolinsky $<$ Zujdivsky $<$ Sofiivsky- $15<$ Galle $<$ Sofiivsky- $1<$ ordinary filbert $<$ Pavlenko's gift.

Under the weather conditions of the wintering of 2015-2016 the varietal physiological response to the provoking thaws was manifested especially brightly. It allowed with high degree of reliability separate the best varieties of filbert, which plants are able to provide the high frost resistance not only at the beginning of wintering but also during the whole cold period of the year. 
Table 2

The damage of one-year sprouts, anthers and buds of the filbert varieties and forms at the temperature $-35^{\circ} \mathrm{C}$. Artificial freezing, point, winter of 2015-2016

\begin{tabular}{|c|c|c|c|c|c|c|}
\hline \multirow{2}{*}{ Variety, specie } & \multirow{2}{*}{ Anthers } & \multicolumn{5}{|c|}{ Summary point of damage of tissues and buds of one-year sprout } \\
\hline & & Top of sprout & Middle of sprout & Tissues of bud & Node with bud & Totally \\
\hline Pavlenko gift & - & 5,8 & 5,7 & 3,7 & 7 & 18,5 \\
\hline Sofiivsky-1 & - & 7,5 & 6,5 & 3,0 & 7,9 & 21,9 \\
\hline Dolinsky & 5,0 & 10 & 7,7 & 3,7 & 8,3 & 26 \\
\hline Zujdivsky & 5,0 & 9,9 & 7,8 & 3,9 & 8,2 & 25,9 \\
\hline Ordinary filbert (control) & - & 6,9 & 4,9 & 3,5 & 8 & 19,8 \\
\hline Sofiivsky-15 & - & 9,5 & 6,6 & 3,7 & 8,8 & 24,9 \\
\hline Coronchaty & - & 9,9 & 8,9 & 3,5 & 9,4 & 28,2 \\
\hline Galle & - & 8,2 & 7,5 & 3,5 & 7,9 & 23,6 \\
\hline Masterpiece & 5,0 & 9,1 & 8,4 & 5,0 & 11,1 & 28,6 \\
\hline Filbert 85 & 5,0 & 8,5 & 8,3 & 3,8 & 9,7 & 26,5 \\
\hline Lozivsky ball-shaped & - & 9,3 & 7,6 & 4,3 & 11 & 27,9 \\
\hline Cherkesky & - & 9,9 & 7,1 & 4,1 & 10,1 & 27,1 \\
\hline Fukturami & - & 10,4 & 8,2 & 4,3 & 11,9 & 30,5 \\
\hline Dokhidny & - & 9,4 & 8,2 & 4,0 & 9,7 & 27,3 \\
\hline Trapezund & - & 10,9 & 8 & 4,5 & 12,1 & 31 \\
\hline Badius & - & 8,2 & 8,1 & 4,3 & 9,8 & 26,1 \\
\hline Ukraine-50 & - & 10,2 & 7,9 & 3,8 & 9,4 & 27,5 \\
\hline
\end{tabular}

\section{Discussion of the results of research}

According to aforesaid, after abnormal wintering of 2015-2016 the studied filbert plants in the garden conditions were characterized with low and extremely low level of the frost damage. The buds and anthers, most sensitive to the wintering stress-factors, were damaged weakly and moderately. By the summary point of frost damage of tissues of one-year sprouts, especially cambium and also frost resistance of buds and anthers, the most resistance to the extremely changeable weather conditions of the winter of 2015-2016 was inherent to the Pavlenko's gift filbert variety.

Artificial freezing of the variants of experiment at the low negative temperatures at the level $-25,-30$ and $-35^{\circ} \mathrm{C}$ gave unambiguous experimental data that completely corresponded to the main law of winter-hardiness. With the growth of pressure of temperature stress-factor the frost damages of the filbert tissues and organs increased. Let's note the distinct distribution of studied variants by the frost resistance in the cut of varieties at artificial frost at different temperature modes. It stresses the role of variety as an important element of profitable technology of the filbert fruits planting in the more Northern gardening zones.

At the direct freezing of one-year sprout of the studied filbert varieties at the temperature factor $-25^{\circ} \mathrm{C}$ the most damages were endured by the plants of Trapezund and Lozivsky ballshaped. The summary point of freezing of tissues and organs of these varieties was 19,7 and 18,8, that corresponds to the low level of freezing and is not an essential danger for the filbert plants at the active growth and development. 
In Ukraine the frosty periods with temperature lowering to $-25^{\circ} \mathrm{C}$ is rather typical phenomenon. Despite the numerous provoking thaws of the winter of 2015-2016 the plants of the studied filbert varieties kept the high potential of frost resistance even during the forced rest. According to the data of artificial freezing at the temperature $-25^{\circ} \mathrm{C}$, the summary point of the damage of tissues and organs of the variants of experiment was within 10,5-19,7 that is all plants of the experiment are frost resistant. In the varietal cut the studied filbert variants were distributed as following (in direction of increase of the sign manifestation): Trapezund (summary point of damage 19,7), Lozivsky ball-shaped (18,8), Dokhidny (17,5), Dolinsky $(17,4)$, Koronchaty $(16,8)$, Galle $(16,5)$, Ukraine-50 (15,9), Badius $(15,5)$, Sofiivsky-15 $(15,4)$, Masterpiece $(15,1)$, Cherkesky and Futkurami (15,0 points), Filbert $85(14,8)$, Zujdivsky $(13,9)$, ordinary filbert $(12,8)$, Sofiivsky-1 $(11,3)$, Pavlenko's gift $(10,5)$.

Laboratory freezing of the filbert plants at the temperature $-30{ }^{\circ} \mathrm{C}$ revealed the more distinct differences in the frost resistance of the studied variants of experiment. Thus, the plants of the variety Sofiivsky-1, Pavlenko's gift and also ordinary filbert froze insignificantly. The summary point of damage of one-year sprouts, buds and anthers in these variants was low, respectively 18,8 points, 13,9 and 16,8 points. The high level of frost resistance was inherent to the filbert Badius (summary freezing point 18,2). The tissues and organs of the studied plant in this variant of experiment froze only by 2,7 points more that at the effect of temperature factor $-25^{\circ} \mathrm{C}$. The other variants of experiment at freezing with the temperature mode $-30{ }^{\circ} \mathrm{C}$ were characterized with the middle degree of freezing.

Under Ukrainian conditions the temperature lowering to $-35^{\circ} \mathrm{C}$ is registered extremely seldom. But determination of biological possibilities of the studied filbert plants at such temperature effect allows prognosticate the behavior of prospective varieties at introduction farther to the North. It is important to know the adaptive possibilities of filbert varieties relative to the winter and frost resistance on the background of the global changes of the climate. The last ones are already manifested as the change of weather conditions in the concrete gardening region that increase the risks of industrial production of the fruits of this culture.

Incomplete coincidence of the data of frost resistance of the studied variants of filbert under natural conditions and at the different modes of direct freezing is explained by the variety features.

Besides the ability to endure the short strong frosts, the high wither-hardiness is demonstrated only by the filbert plants that are less sensitive to the provoking influence of thaws.

\section{Conclusions}

The complex assessment of winter-hardiness of the filbert varieties and forms, planted in Ukraine, was carried out.

The frost resistance of studied plants completely depended on the variety features.

The studies by the field and instrumental methods proved the sufficient adaptability of the studied variants to the conditions of studied gardening zone.

The best by the frost resistance and potential of winter-hardiness are the varieties and forms of the filbert of Ukrainian selection Sofiivsky-land especially, Pavlenko's gift.

The results of these studies can be used for the planning of assortment at the founding of filbert gardens or in amateur gardening in the garden zones with correspondent climatic conditions.

\section{References}

[1] Balabak, O. A. (2014). Perspektyvy vyroshchuvannia form, sortiv i hibrydiv funduka v Ukraini. Aktualni pytannia suchasnoi ahrarnoi nauky. Kyiv, 117-119.

[2] Kosenko, I. S., Opalko, A. I., Opalko, O. A. (2008). Funduk: prykladna henetyka, selektsiia, tekhnolohiia rozmnozhennia i vyrobnytstvo. Kyiv, 70-72.

[3] Muratov, V. A. (2008). Biokhimicheskaia kharakteristika orekhov funduka i obosnovaniie ikh primeneniia pri poluchenii pishchevykh produktov i biologicheskikh dobavok. Krasnodar, 210.

[4] GOST 16835-81. Iadra orekhov funduka. Tekhnicheskie uslovia (2006). Vved. 1982-07-01. Moscow: Izd-vo standartov, 7. 
[5] GOST 10857-64. Semena maslichnye. Metody opredeleniia maslichnosti (2007). Vved. 196407-01. Moscow: Izd-vo standartov, 5.

[6] Morhun, O. V. (2006). Hospodarsko-biolohichna otsinka novykh sortiv funduka v umovakh Pivnichnoho Lisostepu Ukrainy. Kyiv, 20.

[7] Bergezova, A. A. (2009). Biologicheskiie aspekty sozdaniia syrievykh nasazhdenii plodovykh i iagodnykh kultur v predgornoi zone Severo-Zapadnogo Kavkaza. Maikop, 341.

[8] Balabak, O. A. (2015). Stvorennia ta dobir sortymentu funduka (Corylus domestica Kosenko et Opalko) dlia promyslovykh nasadzhen v Ukraini. Heterozys: dosiahnennia ta problemy: Tezy dopovidei mizhnarodnoi naukovo] konferentsii, prysviachenoi 110-richchiu vid dnia narodzhennia vudatnoho henetyka Yu. P. Miriuty. Uman, 10.

[9] Boniuk, Z. O. (2007). Osoblyvosti fenolohichnoho rozvytku ta zymostiikist tavolh Spiraea L. u Kyievi. Visnyk kyivskoho NU im. T. Shevchenka. Seriia: Introduktsiia ta zberezhennia roslynnoho riznomanittia, 11, 131-142.

[10] Morhun, O. V. (2006). Hospodarsko-biolohichna otsinka novykh sortiv funduka v umovakh Pivnichnoho Lisostepu Ukrainy. Kyiv, 170.

[11] Sukhanova, I. P., Sonko, S. P. (2015). Prahnennia do bioriznomanittia - novyi trend roxvytku stiikoho silskoho hospodarstva. Zberezhennia bioriznomanittia v konteksti staloho rozvytku. Cherkasy: FOP Belinska O. B., 151-153.

[12] Khuzhakhmetova, A. Sh., Bogdanov, A. V. (2012). Adaptatcionnye vozmozhnosti i ekologokhoziajstvennaia perspektiva primeneniia orekhoplodnykh kultur v Nizhnem Povolzhe. Izvestiia Nizhnevolzhskogo agrouniversitetckogo kompleksa: nauka i vysshee professionalnoe obrazovanie, 2 (26), 74-79.

[13] Starostin, V. V. (2006). Oreshki iz svoego sada. Funduk i leshchina: budut li oni rasti v nashem klimate. Flora Price, 8 (79), 36-39.

[14] Sliusarchuk, V. Ye., Onyshchenko, A. S. (2013). Vplyv krytychnykh pohodnykh umov na rozvytok roslyn funduka v DSDLTs «Veseli Bokovenky». Lisivnytstvo i agrolisomeloiratsiia, 122, 71-75. Available at: http://nbuv.gov.ua/j-pdf/lisam_2013_122_11.pdf

[15] Makhno, V. H. (2014). Ispolzovanie roda Corylus v dekorativnom i promyshlennom sadovodstve. Subtropicheskoe i dekorativnoe sadovodstvo, 50, 232-235.

[16] Khuzhakhmetova, A. Sh. (2015). Modeli razvitiia kron vidov i sortov leshchiny v vozrastnom aspekte. Sovremennye problemy nauki i obrazovaniia, 3, 22-26.

[17] Kairov, M. A. (2006). Optimizatcia struktury funduka pri vyrashchivanii na pologikh sklonakh Terskogo khrebta. Nalchik, 126.

[18] Naukovi osnovy ta skladovi haluzevoi prohramy rozvytku horikhivnytstva v Ukraini (2011). Kyiv: Lohos, 100.

[19] Loai, Sakhib Rakhdi Al Marshdi (2014). Rozmnozhennia, rist i plodonoshennia funduka v Livoberezhnomy Stepu Ukrainy. Uman, 19.

[20] Babytskyi, A. I., Kytaiev, O. I., Trofymenko, N. M., Doroshenko, O. K. (2014). Osoblyvosti liodoutvorennia u tkanynach pahoniv maloposhyrenykh derevnykh introdutsentiv rodyny Rosaceae Juss. Introduktsiia roslyn, 4, 84-89.

[21] Bublyk, M. O., Patyka, T. I., Kytaiev, O. I., Makarova, D. H., Kryvoshapka, B. A., Honcharuk, Yu. D., Potanin, D. V. (2013). Laboratorni ta poliovi metody vyznachennia morozostiikosti plodovykh porid i kultur. Kyiv 26.

[22] Semeniutina, A. V. et. al. (2010). Metodicheskie ukazaniia po semenovedeniiu drevesnykh introdutcentov v usloviiakh zasushlivoi zony. Moscow: Rosselkhozakademiia, 57.

[23] Semeniutina, A. V., Ryndin, A. V., Makhno, V. G., Khuzhakhmetova, A. Sh., Kravtcov, I. A. (2011). Nauchno-metodicheskie rekomendatcii po vyrashchivaniiu funduka v zasushlivykh usloviiakh Nizhnego Povolzhia. Sochi: GNU VNIITCiSK Rosselkhozakademii, GNU VNIALMI Rosselkhozakademii, 56. 